\title{
FLORENCE RADIOCARBON DATES III
}

\section{M AZZI, L BIGLIOCCA, and F GULISANO}

Consiglio Nazionale delle Ricerche, Firenze

This list comprises age measurements carried out from January 1976 to July 1976. Dated samples are all of archaeologic interest, from Italian territory. Pretreatment of samples, production of purest $\mathrm{CO}_{2}$ and counting techniques have been described elsewhere (Azzi, 1972; Azzi et al, 1973; Azzi et al, 1974). Ages of samples are calculated using the conventional half-life of $5570 \pm 30 \mathrm{yr}$ and refer to 1950 . Errors are stated in terms of one standard deviation of counting statistics.

ACKNOWLEDGMENTS

We thank submitters for providing financial support.

\section{SAMPLE DESCRIPTIONS}

I. ARCHAEOLOGIC AND HISTORIC SAMPLES

$$
\text { A. Italy }
$$

\section{Grotta Paglicci series}

Charcoal from Grotta Paglicci on left side of Settepenne V on S side of Gargano promontory near Rignano Garganico, $15 \mathrm{~km} \mathrm{E} \mathrm{St} \mathrm{Severo,} \mathrm{prov}$ Foggia, Apulia (41 $\left.39^{\prime} 8^{\prime \prime} \mathrm{N}, 15^{\circ} 36^{\prime} 51^{\prime \prime} \mathrm{E}\right)$. Coll 1972 to 1975 and subm 1975 by A Palma di Cesnola, Ist Antropol e Paleontol Umana, Siena. Layers of this series contain different cultural horizons of Superior Paleolithic Age. Detailed information about the structure of the site was previously reported (Azzi et al, 1974).

\section{F-94. Grotta Paglicci 3,a}

$11,440 \pm 180$

Charcoal from Layer 3,a. Final Epigravettian industry with many geometric miroliths.

F.95. Grotta Paglicci 4,a,c

Charcoal from Layer 4,a,c. Final Epigravettian industry.

F-96. Grotta Paglicei 5,b,c

$13,590 \pm 200$

Charcoal from Layer 5,b,c. Final Epigravettian industry with truncated backed blades.

\section{F-64. Grotta Paglicei 6}

$14,270 \pm 230$

Charcoal from Layer 6 related to final Epigravettian industry.

$$
12,320 \mathrm{BC}
$$

14,820 \pm 210

F.65. Grotta Paglicei 7

Charcoal from Layer 7. Last layer with final Epigravettian industry. 


\section{F-66. Grotta Paglicei 8}

Charcoal from Layer 8. Evolute Epigravettian.

\section{F-67. Grotta Paglicei 9}

Charcoal from Layer 9. Industry like F-66.

\section{F-68. Grotta Paglicei 10}

$15,460 \pm 220$ $13,510 \mathrm{BC}$

$15,270 \pm 220$ $13,320 \mathrm{BC}$

$15,320 \pm 250$

Charcoal from Layer 10. Industry probably related to initial phase of Evolute Epigravettian age.

General Comment (APC): ages of Layers 10 to 8 agree with chronology of Evolute Epigravettian found in Riparo C, Grotta delle Cipolliane, Str 3 (Lecce, Apulia); dates of Layers 7 to 5 resemble Final Epigravettian of Ugento, Lecce (R-271: 14,170 \pm 170; R-272: 13,870 \pm 110) and Riparo Tagliente, Layers 15 and 16 (R-605a: 13,430 \pm 180 ; R-605: 13,330 \pm 160 ). Dates of Layers 4, 3, and 2 can be related to many settlements of Final Epigravettian found in N and S Italy: Grotta Romanelli, Lecce, Layers $\mathrm{A}$ and $\mathrm{B}$ (R-56: 11,930 \pm 520; R-58: 11,800 \pm 600), (Alessio et al, 1964); Grotta Erica, Salerno, Str C, Sec B, Cut 3 and 4 (F-38: 11,275 \pm 360; F-39:

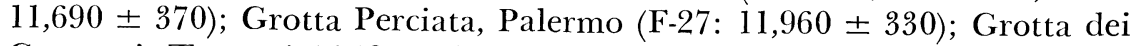
Genovesi, Trapani (F-19: 11,710 \pm 295); Nicchia Gamba, Salerno (F-25: $11,630 \pm 230$ ); Grotta del Romito, Cosenza, Lev 6a (R-299: 11,500 \pm 200$)$; Grotta della Cala, Salerno, Str H (F-21: 12,030 \pm 220); Grotta della Madonna, Praia a Mare, Cosenza, Str X inf (R-293: 12,100 \pm 150 ); Riparo Tagliente, Verona, Str 14 (R-604: 12,000 \pm 400; R-371: 12,040 \pm 170 ), (Alessio et al, 1970).

\section{F.69. Torre Mozza}

$4020 \pm 150$

Charcoal from open site with fireplace and pottery from Località Torre Mozza, com Piombino, prov Livorno (42 $\left.56^{\prime} 33^{\prime \prime} \mathrm{N}, 14^{\circ} 12^{\prime} 08^{\prime \prime} \mathrm{E}\right)$. Coll 1976 by A Galimberti, Ist Antropol, Siena, and subm 1976 by A Palma di Cesnola. Charcoal from base of anthropozoic level with pottery probably related to Final Bronze age. Date does not agree with typology (pers commun).

\section{F-70. Grotta della Cala Atrio}

$29,850 \pm 870$ 27,900 вс

Charred bones from the front part of Cala Cave, Salerno, S Italy $\left(40^{\circ} 00^{\prime} 02^{\prime \prime} \mathrm{N}, 15^{\circ} 22^{\prime} 57^{\prime \prime} \mathrm{E}\right)$. Coll and subm 1975 by P Gambassini, 1st Antropologia, Siena. Layer contains an Aurignacoid lithic industry with carinated, muzzle and scrapers; it underlies $Q$ Layer of Gravettian age (F-22, F-23 and F-24: R, 1973, v 15, p 483).

\section{Castelcivita series}

Charred bones from base (Lev 10-11) and middle (Lev 9) levels of a reddish sand layer in Castelcivita Cave, Salerno, S Italy $\left(40^{\circ} 29^{\prime} 41^{\prime \prime} \mathrm{N}\right.$, 
$\left.15^{\circ} 12^{\prime} 36^{\prime \prime} \mathrm{E}\right)$. Coll and subm 1975 by P Gambassini. Layers contain a lithic industry of an early phase of Upper Paleolithic with marginal backed blades of Dufour type. Fauna include Equus, Cervus, and micromammals (Gambassini, 1976).

\section{F-71. Castelcivita 10,11}

Charred bones from Level 10 and 11 .

\section{F-72. Castelcivita 9}

Charred bones from Level 9.
$32,470 \pm 650$ $\mathbf{3 0 , 5 2 0 ~ B C}$

$32,930 \pm 720$ $\mathbf{3 0 , 9 8 0 ~ B C}$

\section{Dicomano series}

Charcoals from different levels of a Bronze age layer coll in open site of Dicomano, prov Florence (43 $\left.53^{\prime} 26^{\prime \prime} \mathrm{N}, 13^{\circ} 04^{\prime} 26^{\prime \prime} \mathrm{E}\right)$. Coll 1974 and subm 1976 by L Sarti, Ist Antropol, Siena. Analyzed layers, contained broken pottery and lithic industry, lay between 2 alluvial layers.

\section{F.73. Dicomano I}

$2850 \pm 80$

Charcoal, from $-1.45 \mathrm{~m}$ depth between archaeol and alluvial layer, which contains medieval remains.

\section{F-74. Dicomano 2}

$3270 \pm 80$

Charcoal, $-2.50 \mathrm{~m}$ deep in core of archaeol layer.

General Comment (PG): typologically, Dicomano settlement belongs to Middle Bronze age; date agrees with typologic estimate.

\section{Riparo del Belvedere series}

Charcoals from Monfenera, Low Valsesia, prov Vercelli, Piemonte $\left(45^{\circ} 42^{\prime} 30^{\prime \prime} \mathrm{N}, 8^{\circ} 19^{\prime} 30^{\prime \prime} \mathrm{E}\right)$. Samples set a chronologic frame for Belvedere stratigraphy, unique in N Italy, except for Veneto.

\section{F-75. Riparo del Belvedere MF 4 196:0}

$1225 \pm 70$ AD 725

Charcoal from D 15 area, R.2 fireplace, R.2 superior layer. Sample assoc with Late Roman and Early medieval materials. Coll 1969 and subm 1976 by F Fedele, 1st Antropol, Torino. Comment (FF): date establishes chronologic position of Early Medieval settlements in NW Italy and agrees with hypothesis.

\section{F-76. Riparo del Belvedere MF 4 744:1}

$3440 \pm 150$ $1490 \mathrm{BC}$

Charcoal from B 22 NE area, Gr-W fireplace, Grcb unit, R.3 layer. Coll 1972 and subm 1976 by F Fedele. Sample assoc with pottery and bones fragments. Comment (FF): date of this Neolithic settlement in Piemonte establishes chronology of $\mathrm{VBQ}$ culture in NW Italy.

General Comment (FF): first 2 dates of these cultures found in NW Italy. 


\section{St Martin de Corléans series}

Charcoal from prehistoric and archaeol settlement of St Martin de Corléans, from W suburbs of Aosta, Val d'Aosta $\left(45^{\circ} 27^{\prime} \mathrm{N}, 17^{\circ} 40^{\prime} \mathrm{E}\right)$ at $+586 \mathrm{~m}$, near St. Martin de Corléans Church. Samples coll in N part of settlement, which was divided in 2 areas, called, respectively, St Martin Nord and St Martin Sud. Samples belong to a large settlement containing Megalithic constructions raised between end of Neolithic and Eneolithic ages. Materials analyzed coll 1969 to 1971 and subm 1975 by $F$ Mezzena, Sov Antichità, Aosta.

\section{F-77. St Martin de Corléans P7}

Charcoal from wooden pile, without stone base.

\section{F-78. St Martin de Corléans $P 12$}

$5020 \pm 180$

Charcoal from wooden pile, with stone base.

\section{F-79. St Martin de Corléans P 13}

$325 \pm 170$

Charcoal from wooden pile, without stone base.

\section{F-80. St Martin de Corléans P 15}

170

Charcoal from wooden pile, with stone base.

\section{F-81. St Martin de Corléans P 16}

Charcoal from wooden pile, with stone base.

\section{BC}

\section{F-82. St Martin de Corléans $\mathbf{P} 17$}

$4910 \pm 200$

Charcoal from wooden pile, with stone base.

2960 BC

F-83. St Martin de Corléans P 19

$4450 \pm 180$ 2250 BC

Charcoal from wooden pile, without stone base.

General Comment (FM): samples were found in big holes, in which were erected probably totemic piles, with alignment NE-SW; perhaps settlement was a worship area (Mezzena, 1974).

\section{Isola Santa series}

Charcoal from an open settlement with Mesolithic industry in Isola Santa, in Turrite Secca R Valley, Alpi Apuane, com Careggine, prov Lucca $\left(44^{\circ} 03^{\prime} 48^{\prime \prime} \mathrm{N}, 14^{\circ} 15^{\prime} 22^{\prime \prime} \mathrm{E}\right)$. Samples coll and subm 1975 by C Tozzi, lst Antropol, Pisa.

\section{F-89. Isola Santa L 3}

$$
1270 \pm 120
$$

\section{AD 680}

Charcoal from L 3 Layer, probably disturbed, supposition confirmed by date that is too recent and does not agree with typology. 
F-90. Isola Santa $L 4$ a,b,c

Charcoal from superior part of Layer L 4.

\section{F-91. Isola Santa, L 4 d,e}

Charcoal from inferior part of Layer L 4 .

General Comment (CT): F-90 and -91 oldest dates of Mesolithic settlements (Sauveterroid type) and agree with absolute chronology given by Epipaleolithic and Upper Paleolithic of Adige Valley deposits.

\section{F-92. S Maria di Leuca}

$4050 \pm 140$

Charcoal from Level 5 of Sec $\mathrm{C}$ in Bronze age village of S Maria di Leuca, prov Lecce (39 $\left.47^{\prime} \mathrm{N}, 18^{\circ} 22^{\prime} \mathrm{E}\right)$. Coll 1975 by G Cremonesi, Univ Lecce, and subm 1975 by $C$ Tozzi. Sample from a level in which a fireplace and much pottery of Apenninic culture were found. Date is probably too old topologically.

\section{F-93. Catignano}

Charcoal from Structure 59 in Neolithic village of Catignano, prov Pescara $\left(42^{\circ} 21^{\prime} 27^{\prime \prime} \mathrm{N}, 13^{\circ} 44^{\prime} 08^{\prime \prime} \mathrm{E}\right)$. Coll and subm 1975 by C Tozzi. Date seems too recent; in relation to pottery and stratigraphy of Grotta dei Piccioni and Grotta S Angelo, Catignano village is older than beginning of Ripoli culture.

\section{REFERENCES}

Alessio, M, Bella, F, Bachechi, F, and Cortesi, C, 1967, University of Rome carbon-14 dates V: Radiocarbon, v 9, p 346-367.

Alessio, M, Bella, F, and Cortesi, C, 1964, University of Rome carbon-14 dates II: Radiocarbon, $\mathrm{v} 6, \mathrm{p} 79$.

Alessio, M et al, 1970, University of Rome carbon-14 dates VIII: Radiocarbon, v 12,

p 599-616.
Azzi, C M, 1972, Costruzione e messa a punto di un impianto per datazioni Framite $\mathrm{C}^{14}$ con il metodo a gas: Riv Sci Preist, v 28, p 197-209.

Azzi, C M, Bigliocca, L, and Piovan, E, 1973, Florence radiocarbon dates I: Radiocarbon, v 15, p 479-487.

1974, Florence radiocarbon dates II: Radiocarbon, v 16, p 10-14.

Broglio, A, 1972, Cronologia delle culture del Paleolitico superiore, dell'Epipaleolitico e del Neolitico della Valle Padana: Boll Centro Camuno studi preist, v 8, p 47-79.

Fedele, F, 1975, Scoperte e ricerche di archeologia medioevale sul Monfenera (Valsesia): Boll storico-bibliografico subalpino 73 (I), p 269-286.

1973, Scoperta di una stazione Vaso a Bocca Quadrata sul Monfenera (Valsesia): Rapporto preliminare, Preistoria Alpina 9, p 151-222.

Gambassini, P, 1976, Grotta di Castelcivita, Notiziario, Paleolitico, Campania: Riv Sci Preist, $\mathrm{v} 31$.

Mezzena, F, 1974, L'area Megalitica di Aosta: Duria, v 1.

Palma di Cesnola, A, 1967, L'Epigravettiano della Grotta Paglicci nel Gargano: Riv Sci Preist, v 22, fasc 1.

1972a, Scoperta di una sepoltura Gravettiana nella Grotta Paglicci: Riv Sci Preist, v 27, fasc 1 .

1972b, Oggetti d'arte mobiliare di etè Gravettiana ed Epigravettiana nella Grotta Paglicci: Riv Sci Preist, v 27, fasc 2. 